$\sqrt{B}$

J. Bio-Sci. 28: 33-41, 2020

ISSN 1023-8654

http://www.banglajol.info/index.php/JBS/index

DOI: https://doi.org/10.3329/jbs.v28i0.44708_

\title{
ISOLATION OF BACTERIA FROM DIESEL CONTAMINATED SOIL FOR DIESEL REMEDIATION
}

\author{
OA Oyewole ${ }^{1^{*}}$, SS Leh-Togi Zobeashia ${ }^{2}$, OE Oladoja ${ }^{1}$, IO Musa $^{1}$ and IT Terhemba ${ }^{1}$ \\ ${ }^{1}$ Department of Microbiology, Federal University of Technology Minna, Nigeria \\ ${ }^{2}$ National Biotechnology Development Agency, Lugbe Abuja, Nigeria
}

\begin{abstract}
This study is aimed at isolating bacterial species that inhabit diesel contaminated soil and also screened these isolates for the ability to be used for remediating diesel contaminated environment using their potential to degrade diesel as carbon and energy source. Top soil sample was collected from an ancient diesel-powered generator house in Minna, Nigeria, in a sterilized plastic container while diesel oil was obtained from local petrol bunk. Four bacterial isolates were isolated from the diesel contaminated soil sample and were screened for their ability to degrade diesel using mineral salt medium (MSM). The isolates with highest biodegradation potential were identified as Bacillus subtilis and Bacillus cereus. The optimum $\mathrm{pH}(5,6,7$ and 8$)$ and hydrocarbon concentration $(1 \%, 2 \%, 5 \%$ and $10 \%)$ of the isolate was determined by spectrophotometry and the result revealed that the optimum $\mathrm{pH}$ for biodegradation of diesel by Bacillus subtilis and Bacillus cereus, was 7 (1.170) and 8 (1.745) respectively while the optimum hydrocarbon concentration degradation for both isolates was $5 \%$ (2.22) and $1 \%(2.37)$ respectively. The results of this study showed that these isolates were able to degrade diesel and can be useful for large scale bioremediation of diesel contaminated soils.
\end{abstract}

Key words: Bacillus cereus, Bacillus subtilis, Biodegradation, Diesel, Spectrophotometry

\section{Introduction}

Petroleum hydrocarbons are very vital for power supply, heating and vehicles, which are essential part of human existence (Mohammad et al. 2017). The increase in the use of petroleum products globally has led to an immense increase in environmental contamination by diesel, spent engine oil or jet fuel (Husaini et al. 2008). Consequently, pollution by petroleum products is one of the most common problems in the environment (Diana et al. 2017). Diesel varies according to their origin and method of production and is like heating oil. The colour of diesel fuels varies from colourless to brown and their water solubility in $20^{\circ} \mathrm{C}$ is about $5 \mathrm{mg}-1$ and log Kow 3.3-7.06 (Adeyemo et al. 2013, Tudararo et al. 2017). Petroleum derived diesel is composed of many components including aromatic hydrocarbons (23.9\%), cycloalkanes (33.4\%) and nalkanes (42.7\%). Within diesel, the n-alkanes and aromatic hydrocarbons, which have relatively low molecular weight, have been reported to be easily degraded through microbial action (Tudararo et al. 2017). The average chemical formula for common diesel fuel is $\mathrm{C}_{12} \mathrm{H}_{24}$, ranging approximately from $\mathrm{C}_{10} \mathrm{H}_{20}$ to $\mathrm{C}_{12} \mathrm{H}_{28}$ (Thomas et al. 2012). Diesel fuels are therefore partly soluble in water and can bioaccumulate in tissues.

Diesel oil is highly complex in nature. It is very difficult to understand the degradation mechanism (Ramadha et al. 2013). The use of microorganisms is one of the best methods to degrade diesel contaminated soil during bioremediation process (Nandhini et al. 2014). This could be done through bioaugmentation or

*Author for correspondence: oa.oyewole@futminna.edu.ng 
through bio stimulation. However, it is known that hydrocarbon biodegradation in soil can be limited by many factors such as, microorganism type, nutrients, $\mathrm{pH}$, temperature, moisture, oxygen, soil properties and contaminant concentration (Anjana et al. 2014, Nandhini et al. 2014). Soil bioremediation considers the health of the soil ecosystem along with the remediation efficiency (Sharma and Rehman 2009). Diesel oil is a major petroleum product and constitutes a major source of pollution in our environment. With the combined dependence on diesel oil by some vehicles and generators, greater quantities are being transported over long distances. Therefore, diesel oil gets into the environment through wrecks of oil tankers carrying diesel oil and motor mechanics (Nwaogu et al. 2008). Diesel fuels have been observed to cause skin irritation and tumorigenic response in mice. Diesel causes eye and skin irritation in humans, but otherwise, its effects on humans are poorly investigated, nevertheless, it is considered to be harmful and possibly carcinogenic to humans since it contains polyaromatic hydrocarbons (PAHs) that create a risk for human health because of their carcinogenic, mutagenic and teratogenic properties (Antagana 2008). Oil spillages pollute our environment. Most of the oil spillage occurs in Nigeria, the United States and United Arab countries. Oil spillage affects the marine environment, which induces stress and change in the health of the aquatic environment condition. It also affects the activities of soil microbes (Duran and Cravo-Laureau 2016, Xu et al. 2018).

Diesel pollutes the environment during accidents of motor vehicles, oil tanks, or ship carrying diesel oil. The spillages in the agricultural land affect the soil and growth of the plants. Spillage in the marine condition affects the aquatic living environment (Karthika et al. 2014). The common major global environmental pollution is due to the combustion of diesel fuel, crude oil and petroleum compound. These hydrocarbons are mostly used as primary source of energy (Maddela et al. 2017). Although conventional methods of removing oil spills include; using dispersants or basically collecting the oil plume or other active remediation techniques such as dig and haul, pump and treat, heating and evaporation and soil washing can be used to treat soils polluted with petroleum hydrocarbons. These techniques are generally expensive and can lead to incomplete decomposition of contaminants (Junko et al. 2018). Due to this fact, alternative biotechnological cleanup methods such as bioremediation and phytoremediation have raised much interest in the last decades (Anjana et al. 2014).

The term of bioremediation has been made of two parts: "bios" means life and refers to living organisms and "to remediate" that means to solve a problem. "Bioremediate" means to use biological organisms to solve an environmental problem such as contaminated soil or groundwater. Bioremediation is the use of living microorganisms to degrade environmental pollutants or to prevent pollution. In other words, it is a technology for removing pollutants from the environment thus, restoring the original natural surroundings and preventing further pollution (Sasikumar and Papinazath 2003). The versatility of microbes to degrade a vast array of pollutants makes bioremediation a technology that can be applied in different soil conditions (Sylvia et al. 2005). Though it can be inexpensive and in situ approaches can reduce disruptive engineering practices, bioremediation is still not a common practice (Eric and Bruno 2017). The ultimate natural mechanism by which hydrocarbon polluted environment can be clean is through biodegradation, which the hydrocarbons are primarily degraded by bacteria, yeast, and fungi where the efficiency of biodegradation ranges from $6 \%$ to $82 \%$ for soil fungi, $0.13 \%$ to $50 \%$ for soil bacteria, and $0.003 \%$ to $100 \%$ for marine bacteria. This has prompted many scientists to report that mixed populations with overall broad enzymatic capacities are required to breakdown complex mixtures of hydrocarbons such as diesel in soil, fresh water, and marine environments (Eskander and Saleh 2017).

The most active agents in diesel degradation are the bacteria, which act majorly as the primary degraders of spilled oil in environment, and several bacteria are even known to feed exclusively on hydrocarbons as their source of carbon. They include the following bacterial genera, Bacillus (Hameed 2006), Pseudomonas 
(Huston et al. 2002), Streptomyces (Infante et al. 2014), fungi such as Trametes versicolor and Pleurotustu berregium (Adenipekun and Lawal 2012), algae such as Monoraphidium braunii and Amphora coffeaeformis (Gattullo et al. 2012) and plants such as Brassica juncea and Helianthus annuus (Khokhar et al. 2012). The aim of this study is to isolate bacteria from diesel contaminated soil and use it to remediate a diesel contaminated soil.

\section{Materials and Methods \\ Collection of soil sample and diesel}

Top soil sample was collected from an ancient diesel-powered generator house in Minna, Nigeria, in sterilized plastic containers and taken to the microbiology laboratory of Federal University of Technology Minna, Nigeria. Diesel used in this study was obtained from local petrol bunk, Minna, Nigeria.

\section{Isolation of bacteria from contaminated soil}

Soil samples were serially diluted, $0.1 \mathrm{ml}$ of the diluted samples spread on the surface of nutrient agar plates and the plates incubated at $37^{\circ} \mathrm{C}$ for $24 \mathrm{~h}$. The colonies obtained from the agar plates were further subcultured to obtain pure colonies.

\section{Screening of isolate for diesel degradation}

The degradation studies were performed in mineral salt medium (MSM) that contains diesel as the sole source of carbon. The MSM consists of $\mathrm{NH}_{4} \mathrm{Cl}-0.4 \mathrm{~g} / \mathrm{l}, \mathrm{KH}_{2} \mathrm{PO}_{4}-1.2 \mathrm{~g} / \mathrm{l}, \mathrm{K}_{2} \mathrm{HPO}_{4} .3 \mathrm{H}_{2} \mathrm{O}-1.8 \mathrm{~g} / \mathrm{l}$ and trace amounts of $\mathrm{MgSO}_{4} .7 \mathrm{H}_{2} \mathrm{O}-0.2 \mathrm{~g} / \mathrm{l}, \mathrm{FeSO}_{4} .7 \mathrm{H}_{2} \mathrm{O}-0.01 \mathrm{~g} / \mathrm{l}$ and $\mathrm{NaCl}-0.1 \mathrm{~g} / \mathrm{l}$. The isolated bacterial species from site were cultured on solidified mineral salt medium containing diesel and incubated for 3 days at $37^{\circ} \mathrm{C}$. The growths of the isolated bacterial species were monitored at regular intervals by visible development of bacterial colonies on the media.

\section{Identification of selected bacteria isolates}

Screened and selected diesel degrading bacteria were identified by cultural, morphological and biochemical characteristics, following the methods of Buchanan and Gibbons (1974).

\section{Effects of $\mathrm{pH}$ on degradation rates}

The medium contains $\mathrm{K}_{2} \mathrm{HPO}_{4}(1.8 \mathrm{~g} / \mathrm{l}), \mathrm{KH}_{2} \mathrm{PO}_{4}(1.2 \mathrm{~g} / \mathrm{l}), \mathrm{NH}_{4} \mathrm{Cl}(0.4 \mathrm{~g} / \mathrm{l}), \mathrm{MgSO}_{4} .7 \mathrm{H}_{2} \mathrm{O}(0.2 \mathrm{~g} / \mathrm{l}), \mathrm{NaCl}(0.1$ $\mathrm{g} / \mathrm{l}), \mathrm{FeSO}_{4} .7 \mathrm{H}_{2} \mathrm{O}(0.01 \mathrm{~g} / \mathrm{l})$, carbon source (1\% diesel), and distilled water (1liter) with initial pH of 8.01 . The media was dispensed into nine $150 \mathrm{ml}$ conical flasks (98 $\mathrm{ml}$ each) labeled appropriately the $\mathrm{pH}$ of first two were adjusted to 5, 6, 7 and 8 using dilute $\mathrm{HCl}$ acid to reduce the $\mathrm{pH}$ and dilute $\mathrm{NaOH}$ to increase the $\mathrm{pH}$. The medium with hydrocarbons was sterilized by autoclaving at $121^{\circ} \mathrm{C}$ for $15 \mathrm{~min}$. After cooling to room temperature $\left(28^{\circ} \mathrm{C} \pm 2\right), 1 \mathrm{ml}$ each of the isolates in $24 \mathrm{~h}$ nutrient broth were inoculated into the sterile MSM and incubated at $37^{\circ} \mathrm{C}$ in an incubator shaker at $170 \mathrm{rpm}$. The ability of the isolate to degrade diesel oil was demonstrated in terms of increase in the microbial biomass evident by increase in turbidity of the media. The rate of utilization was monitored on the first day (day zero) of the study and subsequently at 3 days interval for 27 days. The UV-VIS spectrophotometer (model 752, China) was used to measure the absorbance rate by optical density at $540 \mathrm{~nm}$. On each day, $2 \mathrm{ml}$ per single treatment were analyzed for the rate of diesel absorbance using the methods of Udeme and Antai (1988). Each of the $2 \mathrm{ml}$ sample treatment at pH 5, 6, 7 and 8 samples was shaken vigorously for 3 minutes using a cyclo vortex mixer then transferred into the cuvette for analysis using the spectrophotometer. 


\section{Effect of hydrocarbon concentration on degradation rates}

The basal mineral salt medium containing $\mathrm{K}_{2} \mathrm{HPO}_{4}(1.8 \mathrm{~g} / \mathrm{l}), \mathrm{KH}_{2} \mathrm{PO}_{4}(1.2 \mathrm{~g} / \mathrm{l}), \mathrm{NH}_{4} \mathrm{Cl}(0.4 \mathrm{~g} / \mathrm{l}), \mathrm{MgSO}_{4} .7 \mathrm{H}_{2} \mathrm{O}$ $(0.2 \mathrm{~g} / \mathrm{l}), \mathrm{NaCl}(0.1 \mathrm{~g} / \mathrm{l}), \mathrm{FeSO}_{4} .7 \mathrm{H}_{2} \mathrm{O}(0.01 \mathrm{~g} / \mathrm{l})$, carbon source $(1 \%, 2 \%, 5 \%$ and $10 \%$ diesel), and distilled water (1liter) with initial of $\mathrm{pH} 8.01$. Since optimum $\mathrm{pH}$ for the degrading isolates was already determined, the $\mathrm{pH}$ of the medium was adjusted $\mathrm{pH}$ to 7 and 8 using dilute $\mathrm{HCl}$ and $\mathrm{NaOH}$ for Bacillus subtilis and Bacillus cereus respectively.

The medium was dispensed into nine $150 \mathrm{ml}$ conical flasks (98 $\mathrm{ml}$ each) and labeled appropriately, $1 \mathrm{ml}, 2$ $\mathrm{ml}, 5 \mathrm{ml}$ and, $10 \mathrm{ml}$ of diesel were added to two conical flasks each. A control was set up without addition of diesel. The medium with hydrocarbons was sterilized by autoclaving at $121^{\circ} \mathrm{C}$ for $15 \mathrm{~min}$. After cooling to room temperature $\left(28^{\circ} \mathrm{C} \pm 2\right), 1 \mathrm{ml}$ each of the isolates in $24 \mathrm{~h}$ nutrient broth were inoculated into the sterile mineral salt media and incubated at $37^{\circ} \mathrm{C}$ in an incubator shaker at $170 \mathrm{rpm}$. The ability of the isolate to degrade diesel was demonstrated in terms of increase in the microbial biomass evident by increase in turbidity of the media. The rate of utilization was monitored on the first day (day zero) of the study and subsequently at 3 days interval for 27 days. The UV-VIS spectrophotometer (model 752, China) was used to measure the absorbance rate by optical density at $540 \mathrm{~nm}$. On each day, $2 \mathrm{ml}$ per single treatment were analyzed for the rate of diesel absorbance using the methods of Udeme and Antai (1988). Each of the $2 \mathrm{ml}$ sample treatment was shaken vigorously for 3 min using a cyclo vortex mixer then transferred into the cuvette for analysis using the UV-VIS spectrophotometer (model 752, China).

\section{Results}

\section{Bacteria isolate screened for diesel degradation potential}

Four distinct bacterial colonies were obtained from diesel polluted soil and these four isolates were screened for diesel degradation potential, which was determined based on the ability of isolates to grow on mineral salt medium supplemented with diesel oil $(1 \%)$. It was observed that only two of the four has the ability to degrade diesel and the both isolates are creamy mucoid Gram-positive rods. The identification of isolates based on biochemical test indicates that species characters were like Bacillus subtilis and Bacillis cereus.

The identification of isolates based on biochemical test indicates that species characters were like Bacillus subtilis and Bacillis cereus. The result indicated positive reaction of both isolates to Gram reaction (rod shapes), Citrate, Voges Proskauer, catalase, motility, spore, and Simon citrate tests while negative reaction was obtained for methyl red and indole tests. However, $B$. subtilis gave a positive reaction to oxidase and nitrate reduction tests while $B$. cereus gave a negative reaction to these tests.

\section{Effects $\mathrm{pH}$ on bacterial growth during degradation}

The effect of pH (5, 6, 7 and 8) on the growth of Bacillus subtilis and Bacillus cereus is represented in Fig. 1 and 2, respectively and it was observed that the lowest absorbance (0.007) was at pH 5 and highest (1.170) at $\mathrm{pH} 7$ for Bacillus subtilis while on the other hand, Bacillus cereus had its lowest absorbance at $\mathrm{pH} 5$ (0.132) and highest at pH 8 (1.745). 


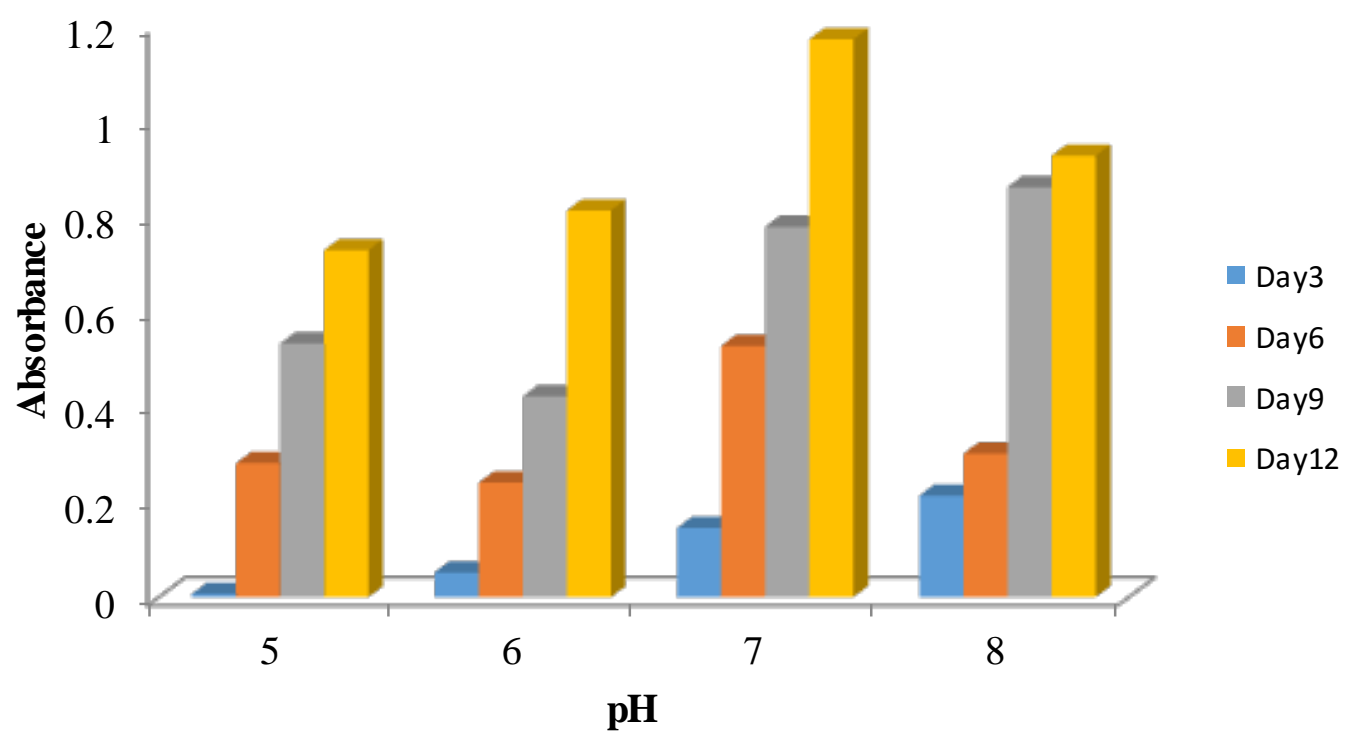

Fig. 1. Effect of pH on the rate of diesel degradation by Bacillus subtilis.

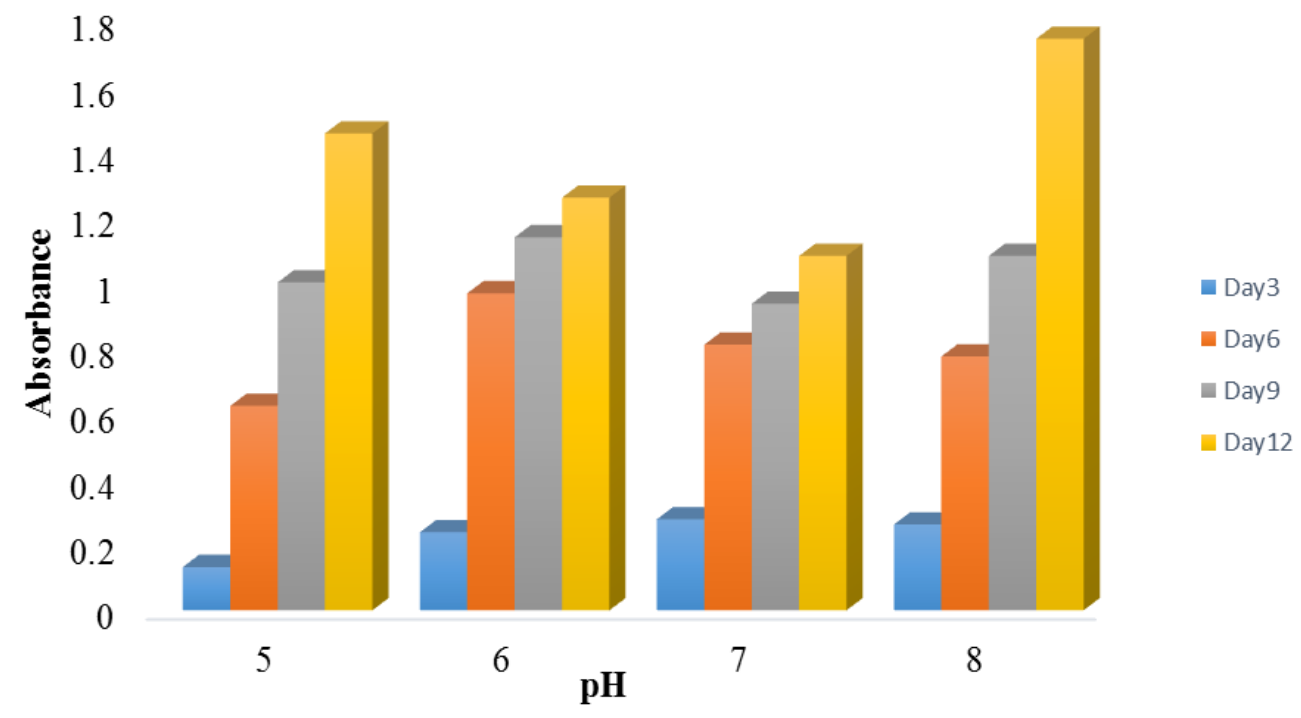

Fig. 2. Effect of pH on rate of diesel degradation by Bacillus cereus. 


\section{Effect of diesel concentration on bacterial growth during biodegradation}

Microbial growth decreased with increase in diesel oil concentration of 1\%,2\%, 5\% and 10\%. From Fig. 3 and 4 , it is observed that optimum hydrocarbon concentration for both Bacillus subtilis and Bacillus cereus is $\leq 5 \%$ with the former having its highest absorbance (2.22) at $5 \%$ and the later at $1 \%(2.37)$

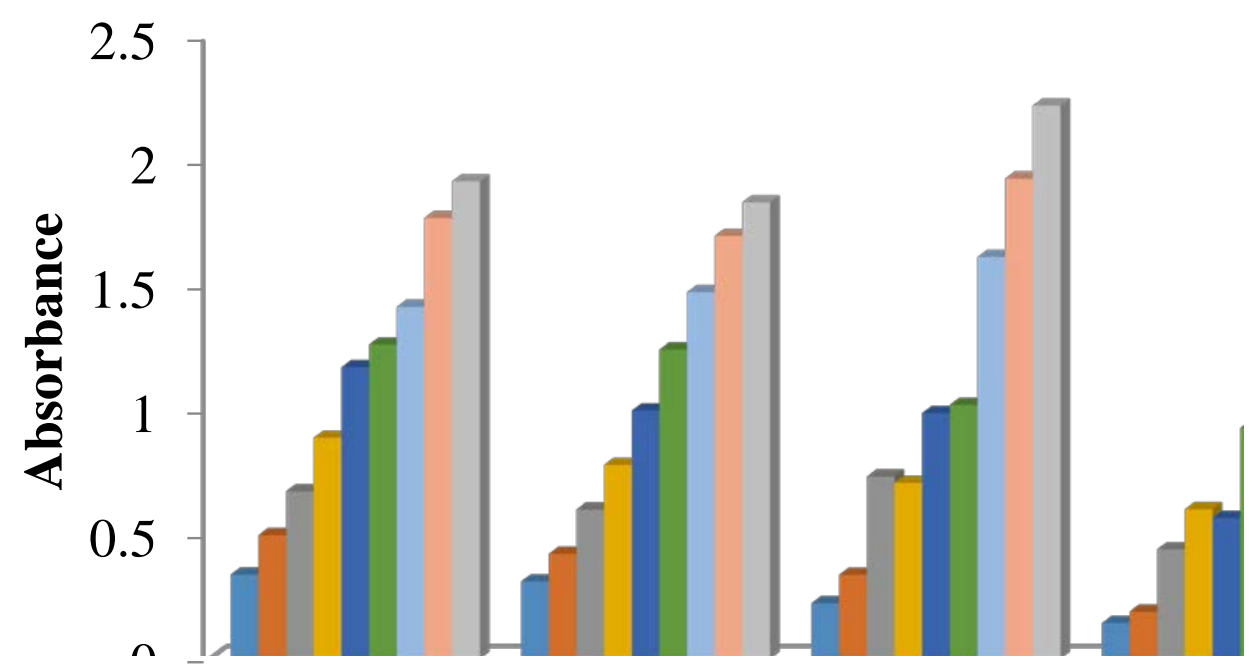

Fig. 3. Effect of hydrocarbon concentration on the rate of diesel degradation by Bacillus subtilis.

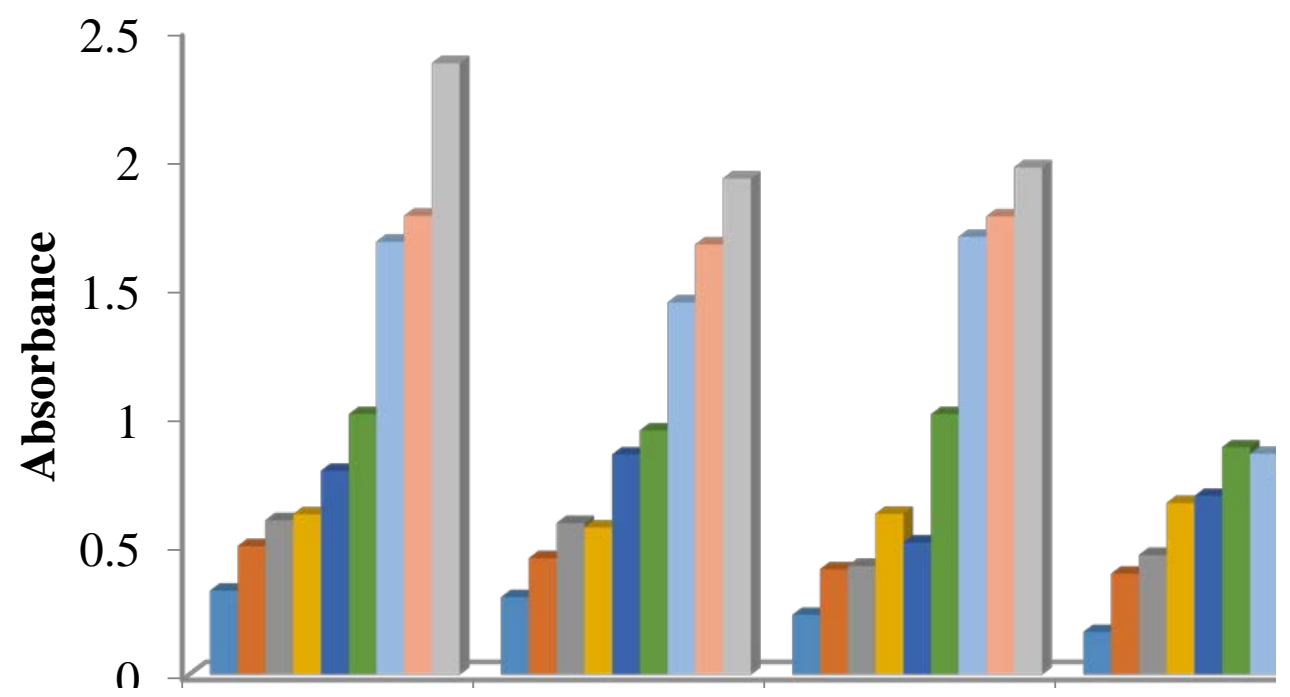

Fig. 4. Effect of hydrocarbon concentration on the rate of diesel degradation by Bacillus cereus. 


\section{Discussion}

Four bacterial isolates were obtained from this study, amongst which only two were diesel degraders. These bacteria could be isolated because they survived the diesel contamination in the soil from which they were obtained and this is due to the presence of enzymes and genes that gives them an edge over other bacteria that could not survive in the seemingly harsh environment due to diesel pollution. Haritash and Kaushik (2009) demonstrated that microorganisms are the main degraders of hydrocarbons. Several strains of Bacilli, including Bacillus subtilis and Bacillus cereus have been reported by several authors - Nikhil et al. (2013), Borah and Yadav (2014), Gayathri et al. (2014), Shekhar et al. (2014) and Al-Dhabaan (2019) to have the capacity to degrade diesel contaminated soil.

Microorganisms are known to have optimum conditions for their activities including degradation of xenobiotics. In this study the optimum $\mathrm{pH}$ and hydrocarbon concentrations for degradation of diesel were determined. A regular steep increase in the absorbance rates up to $\mathrm{pH} 7$ was observed, this is followed by an irregular decrease in the absorbance rates at pH 8 (Fig. 1-2). It is also evident that pH 7.0 was the optimum $\mathrm{pH}$ for the degradation of diesel by Bacillus subtilis and the optimum hydrocarbon concentration was $5 \%$. This is similar to the result obtained by Palanisamy et al. (2014) for the degradation of diesel by Acinetobacter baumannii although with a lower hydrocarbon concentration at 4\%. Similarly, Luo et al. (2013) and Sathishkumar et al. (2008) also reported a neutral pH for diesel and crude oil biodegradation respectively. On the other hand, the optimum $\mathrm{pH}$ for diesel degradation by Bacillus cereus was found to be 8.0. This is at variance with reports of Whang et al. (2009) and Xia et al. (2012) who reported a pH of 7.2 and 7.4 respectively for biodegradation of diesel. Although Sihag et al. (2014) reported a pH range of 6.5-8.0 as optimum for microbial degradation of diesel

\section{Conclusion}

In this study, Bacillus subtilis and Bacillus cereus were able to degrade diesel at an optimum $\mathrm{pH}$ of 7 and 8 , respectively and the highest degradation occurred at a diesel concentration of $1 \%$ and $5 \%$ respectively for both isolates. These results revealed that these isolates possess ability to degrade diesel and can be used as bioactive agent for large scale bioremediation of diesel in diesel contaminated soils.

\section{References}

Adenipekun CO and Lawal R (2012). Uses of mushrooms in bioremediation: A review- Biotechnology Molecular Biology Review, 7(3): 62-68.

Adeyemo IA, Agbolade JO and Oke O (2013). Microflora associated with diesel powered generators contaminated soil arena of obafemi awolowo and oduduwa universities In Ile -Ife, Osun State, Nigeria Global Journal of Biology, Agriculture and Health Sciences, 2(4): 65-73.

Al-Dhabaan FA (2019). Morphological, biochemical and molecular identification of petroleum hydrocarbons biodegradation bacteria isolated from oil polluted soil in Dhahran, Saud Arabia. Saudi Journal of Biological Sciences, 26(6):1247-1252.

Anjana S, Poonam K and Meenal BR (2014). Biodegradation of diesel hydrocarbon in soil by bioaugumentation of Pseudomanas aeruginosa: a laboratory scale study. International Journal of Environmental Bioremediation and Biodegradation, 2(4): 202-212.

Antagana $\mathrm{HI}$ (2008). Compost bioremediation of hydrocarbon contaminated soil inoculated with organic manure. African Journal of Biotechnology, 7(10): 1516-1525.

Borah D and Yadav RNS (2014). Biodegradation of diesel, crude oil, kerosene and used engine oil by a newly isolated Bacillus cereus strain DRDU1 from an automobile engine in liquid culture. Arabian Journal for Science and Engineering, 39(7): 5337-5345. 
Buchanan RE and Gibbons NE (1974). Bergey's Manual of Determinative Bacteriology. 8th Edition, Williams and Wilkins, Baltimore.

Diana MC, Michaela AS and Aykan K (2017). Crude oil contaminated sites: evaluation by using risk assessment approach. Sustainability, 9(1365): 1-16.

Duran R and Cravo-Laureau C (2016). Role of environmental factors and microorganisms in determining the fate of polycyclic aromatic hydrocarbons in the marine environment. FEMS Microbiology Reviews, 40(6): 814-830.

Eric JH and Bruno LP (2017). Bioremediation; a general outline. Indiana Department of Environmental Management, 3(1): 1-14.

Eskander SB and Saleh HM (2017). Biodegradation: Process Mechanism. Journal of Environmental Science and Engineering, 8: 1-31.

Gayathri E, Bharathi B and Natarajan S (2014). Isolation, identification and characterisation of diesel degrading bacteria. International Journal of Current Research, 6(6): 7295-7300.

Gattullo CE, Bährs H, Steinberg CW and Loffredo E (2012). Removal of bisphenol a by the freshwater green alga Monoraphidium braunii and the role of natural organic matter. Science of the Total Environment, 4(16): 501-506.

Hameed MSA (2006). Continuous removal and recovery of lead by alginate beads free and alginate-immobilized Chlorella vulgaris. African Journal of Biotechnology, 5(1): 1819-1823.

Haritash AK and Kaushik CP (2009). Biodegradation aspects of polycyclic aromatic: a review. Journal of Hazardmater, 169(4): 1-15.

Husaini A, Roslan HA, Hill SKY and Ang CH (2008). Biodegradation of aliphatic hydrocarbons by indigenous fungi isolated from used motor oil contaminated sites. World Journal of Microbiology and Biotechnology, 20(12): 27892797.

Huston WM, Jennings MP and McEwan AG (2002). The multi-copper oxidase of Pseudomonas aeruginosa is a ferroxidase with a central role in iron acquisition. Molecular Microbiology, 1(45): 1741-1750.

Infante JC, De Arco RD and Angulo ME (2014). Removal of lead, mercury and nickel using the yeast Saccharomyces cerevisiae. Revista MVZ Córdoba, 2(19): 4141-4149.

Junko N, Yoshige K, Takeshi K and Mink Z (2018). Decomposition of gasoline hydrocarbons by natural microorganisms in Japanese soils. Geosciences, 8(35): 1-9.

Karthika R, Gopinat LR, Achaya S and Bhuvaneswari R (2014). Isolation of diesel degrading bacteria, identification of Catechol gene and its biogas production. Journal of Environmental Science, Toxicology and Food Technology, 8(10): 76-82.

Khokhar AL, Rajput MT, Ahmed B and Tahir SS (2012). Checklist of flowering plants used in phytoremediation found in Sindh, Pakistan. Sindh University Research Journal (Science Series), 44: 497-500.

Luo Q, Zhang J-G, Shen X-R, Sui X and Fan ZQ (2013). Characterization of a novel diesel oil-degrading Pseudomonas sp. strain F4. Fresenius Environ., 22: 689-697.

Maddela NR, Rodriguez L, Senaguano SH, Ricardo EB and Kadiyala V (2017). Biodegradation of diesel, crude oil and spent lubricating oil by soil isolates of Bacillus species. Bulletin of Environmental Contamination and Toxicology, 98(5): 698-705.

Mohammad S, Hamid RK, Zahra GN and Thomas HF (2017). Study potential of indigenous Pseudomonas aeruginosa and Bacillus subtilis in bioremediation of diesel contaminated water, Water, Air and Soil Pollution, 228(1): 37-49.

Nandhini P, Jayaprakash R, Srilakshman K, Vasanthi NS, Preethy C and Sudheer K (2014). Diesel biodegradation capacities of indigenous bacterial species isolated from diesel contaminated soil. Journal of Environmental Health Science and Eng., 12(1): 142-159. 
Nikhil T, Deepa V, Rohan G and Satish B (2013). Isolation, characterization and identification of diesel engine oil degrading Bacteria from Garage soil and comparison of their bioremediation potential. International Research Journal of Environment Sci., 2(2): 48-52.

Nwaogu LA, Onyenze GC and Nwabueze RN (2008). Degradation of diesel oil in polluted soil using Bacillus subtilis. African Journal of Biotechnology, 7(12): 1939-1943.

Palanisamy N (2014). Diesel biodegradation capacities of indigenous bacterial species isolated from diesel contaminated soil. Journal of Environmental Health Science, 12(1): 42-56.

Ramadha RS, Jabbar RN and Nour A (2013). Isolation, identification and assessment of the ability of local Streptomyces isolate rom Iraq to utilize crude oil and diesel fuel. AlGafarietal Sientific Research and Impact, 2(1): 9-28.

Sasikumar CS and Papinazath T (2003). Environmental Management: Bioremediation of polluted environment. In: Martin J Bunch, V Madha Suresh and T Vasantha Kumaran, eds., Proceedings of the Third International Conference on Environment and Health, Chennai, India, 15-17 December, pp. 465-469.

Sathishkumar M, Binupriya AR, Baik SH and Yun SE (2008). Biodegradation of crude oil by individual bacterial strains and a mixed bacterial consortium isolated from hydrocarbon contaminated areas. Clean-Soil Air Water, 36: 92-96.

Sharma A and Rehman MB (2009). Laboratory scale bioremediation of diesel hydrocarbon in soil by indigenous bacterial consortium. Indiana Journal of Experimental Biology, 47(6): 766-769.

Shekhar SK, Godheja J and Modi DR (2014). Hydrocarbon bioremediation efficiency by five indigenous bacterial strains isolated from contaminated. International Journal of Current Microbiology and Applied Sciences, 4(3): 892-905.

Sihag S, Pathak H and Jaroli DP (2014). Factor affecting the rate of biodegradation of polyaromatic hydrocarbons (review article). Int J Pure Appl Biosci., 2: 185-202.

Sylvia DM, Hartel PG, Fuhrmann JJ and Zuberer DA (2005). Principles and Applications of Soil Microbiology (2nd ed.). Upper Saddle River NJ Prentice Hall.

Thomas GS, Earl C, Krege MC, Rachel EM, Erica G and Robert LM (2012). Hydrocarbon renewable and synthetic diesel fuel blends stocks: composition and properties. Energy and Fuels, 27(1): 237-246.

Tudararo AL, Iritare M and Ogeleka DF (2017). Bioremediation of diesel contaminated water using indigenous hydrocarbon degrading bacteria. International Journal of Scientific Research in Science and Technology, 3(1): 352360.

Udeme JJ and Antai SP (1988). Biodegradation and mineralization of crude oil by bacteria. Nigerian Journal of Biotechnology, 5: 79-86.

Whang LM, Liu PWG, Ma CC and Cheng SS (2008). Application of rhamnolipid and surfactin for enhanced diesel biodegradation-Effects of $\mathrm{pH}$ and ammonium addition. Journal of Hazard Mater, 164: 1045-1050.

Xia W, Li J, Xia Y, Song Z and Zhou J (2012). Optimization of diesel oil biodegradation in seawater using statistical experimental methodology. Water Science Technol., 66: 1301-1309.

Xu X, Liu W, Tian S, Wang W, Qi Q, Jiang P, Gao X, Li F, Li H and Yu H (2018). Petroleum hydrocarbon-degrading bacteria for the remediation of oil pollution under aerobic conditions: A Perspective Analysis. Front Microbiol., 3(9): 2885. 
